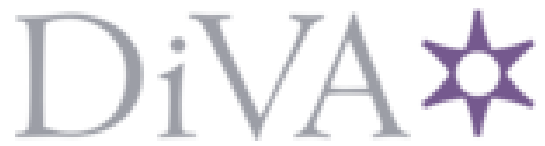

http://www.diva-portal.org

\title{
Postprint
}

This is the accepted version of a chapter published in The Sage Handbook of Propaganda.

Citation for the original published chapter:

Simons, G. (2019)

Syria: Propaganda as a Tool in the Arsenal of Information Warfare

In: Paul Baines, Nicholas O'Shaughnessy and Nancy Snow (ed.), The Sage Handbook of Propaganda (pp. 443-460). Sage Publications

N.B. When citing this work, cite the original published chapter.

Permanent link to this version:

http://urn.kb.se/resolve?urn=urn:nbn:se:uu:diva-400545 


\title{
Chapter 26
}

\section{Syria: Propaganda as a Tool in the Arsenal of Information Warfare}

\section{Greg Simons}

\begin{abstract}
Propaganda is a mechanism of the information domain that attempts to shape and influence the cognitive domain concerning events and processes that are located in the physical domain. It is a very deliberate tool that is intended to mobilise public sentiment through creating an environment that is dominated by an emotional form of logic, often in a very binary 'reality' involving a series of radical opposites.

The use of rhetoric is an essential element in the application of propaganda within the setting of information warfare, which forms of the basis of the appeals and emotional conditioning. This application has been witnessed in the Syrian conflict from the very beginning, where the propaganda of aversion (Assad - "bad") is contrasted against the propaganda of attraction ('rebels' - "good"). Ultimately this concerns the various audiences' perceptions and opinions of the Syrian war and especially the intangible aspects of political legitimacy/illegitimacy. Seeming 'small' or 'trivial' details are in fact key to influencing and persuading an audience to think and act in a pre-determined manner.

This chapter will show the importance and relevance of the details that go into scripting the propagandistic narrative as a means of shaping the cognitive domain through distorted and manipulated material in the information domain, which in turn is used as a means to form public consent on a policy issue. Four newspapers have their content analysed in the first four days in the wake of an alleged chemical attack in Douma, Syria. This content was consistent in nature and followed a propaganda role where media acted as an instrument of war.
\end{abstract}

\section{Introduction}

Taylor (2003: 5) pointed to the inextricable link between propaganda and war, which is a constant throughout the ages. He also warned of the effects, "once war has broken out, propaganda has proved to be a weapon of no less significance than swords, guns or bombs." This 'symbiotic' relationship between war and propaganda is owed in no small part to what Payne (2005) characterises as being the key factors to winning modern wars, which is increasingly dictated by political rather than purely military factors. Political and military 
leaders require a sense of public holding some measure of legitimacy and belief in their military ventures. This creates the need for governments to engage in information operations (including the use of propaganda) to support and enable military operations, before those operations commence and while these operations are being conducted (Western, 2005; DiMaggio, 2009; Zollmann, 2017; Simons \& Chifu, 2018).

This chapter will look at a recent and specific use of propaganda in the Syrian War. While acknowledging that all sides involved in the conflict use propaganda as a communicational means of trying to shape and influence public perception and opinion, the focus of this work will be on the official (government and military) narratives that are present in Western mainstream mass media. In particular, a case study shall look at the chemical weapons event that took place in Douma on the $7^{\text {th }}$ of April 2018, with attention paid to the first days of reporting. The chapter will seek to address the question, how are the propaganda frames operationalised in order to attempt public consent to military intervention?

The first section deals with defining and detailing the role played by propaganda and mass media in attempting to influence public opinion and perception as a means of priming and mobilising global publics in giving their consent to a military intervention. In the second section, a background is given to the Syrian conflict in order to provide the reader with an understanding and appreciation of the very complex nature of this conflict. This all lays the groundwork for the third section that introduces the case study of media coverage of Douma in April 2018 in selected British and US newspapers.

\section{The Role of Propaganda in Opinion and Perception}

There is not an intention to offer the many and varied definitions of a highly loaded word such as propaganda. Needless to say there are many definitions, and there are other chapters in this handbook of propaganda that seek to do this more systematically than I am able to here in this limited space. It is intended to begin with some basic characteristics of propaganda, before moving to how propaganda fits in to the wider information and cognitive domains, and then to briefly examine how these aspects interact during armed conflict. Propaganda is understood to have a persuasive function, intends to reach a sizeable target audience, it is representative of a specific group's agenda, and makes use of faulty reasoning and/or emotional appeals (Taylor, 2003: 1-16; Shabo, 2008: 5). These aspects are aimed at priming and mobilising a selected target audience by shaping an emotionally based environment that manufactures their perception and opinion of events. 
Within the broader realm of information warfare (within which propaganda is situated), there are three domains to be considered: the physical domain, the information domain and the cognitive domain (Alberts et al, 2001: 10). ${ }^{1}$ In terms of the search for political and military influence, the domain that they seek to influence is the informational one in order to enable military operations and foreign policy in the physical domain. A general public's understanding of a reality and 'ground truth' can translate into increasing the possibility of combat or policy effectiveness and dominance. On the intangible side, information exists and is created in the information domain. It is shared and can be subjected to manipulation, which means that the information in it may not accurately reflect the ground truth. This domain concerns the communication of information among and between the various vested actors. The information domain is subject to competition and interference from other actors present, which implies offensive and defensive dimensions to communication activities. The objective is to gain information superiority within the information domain over the adversary or over domestic voices opposed to the government's chosen policy position. The minds of the participants are found in the cognitive domain, which is "where perceptions, awareness, understanding, beliefs, and values reside, and where, as a result of sense making, decisions are made" (Alberts et al, 2001: 13). This is the domain in which physical battles are actually won or lost as it involves such crucial intangibles as leadership, morale, unit cohesion, level of training and experience, situational awareness and public opinion. All content in this domain passes through the filtering process of human perception.

A distinction needs to be made between "information" and "knowledge", where information is the raw material communicated within the information domain concerning people, processes and events occurring in the physical domain. Knowledge is when information communicated from the information domain enters the cognitive domain and an individual has made 'sense' of that data according to their world view and the information supplied. This all concerns the ability of an actor in shaping the perception of others. "Perception involves forming a view of something through intuition or interpretation of available knowledge" (Ministry of Defence, 2010: 3-14). Efforts are directed towards the state of gaining Information Superiority can be said to be achieved when one actor is able to create a relative information advantage over their adversary, which is a mixture of being able to maximize information efficiency whilst simultaneously denying the opponent the ability to

\footnotetext{
${ }^{1}$ For more details on these domains please refer to chapter two in Alberts et al, 2001.
} 
do the same. The efficiency component involves and concerns an actor's ability shape the information space according to the operational requirements and needs (Alberts et al, 2001: 54). Propaganda makes use of deceptive and misleading wording that is designed to be suggestive of another reality in order to influence the cognitive sphere that is in-line with scripted propaganda.

According to Taylor (2003), the 'golden rule' of propaganda when making use of a lie is to lie by omission rather than commission. In practical terms this is a means, for example, to omit the wrongdoings of the 'good' side, whilst emphasizing any wrongdoings of the 'bad' side. The intention is to distract public attention from some acts and focus public outrage on others in order to engineer consent. This raises the question, what exactly is 'scripted' propaganda? This is the tendency to script complex processes and events within a simple Hollywood-like propaganda narrative in order to influence the brand and reputation, and therefore manage the public expectations of the primary actors engaged. Thus actors become scripted and categorised as being 'good' and 'bad', 'saviour' and 'spoiler', 'victim' and 'villain', 'aggressor' and so forth. This can have the effect of creating a simple and subjective façade of a complex social and political environments that can enable the influence of public opinion and perception in order prime ${ }^{2}$ and mobilise audiences according to a manufactured 'reality' in the cognitive sphere.

In order for an actor to succeed in persuading and influencing others, they need to be able to communicate a compelling mass mediated message. It can manifest as an exercise in the masking of interests as values and norms, which in modern warfare is used as a means of accumulating a sense of legitimacy through persuading public perception and opinion of a façade of moral and ethical high ground over an opponent. Zollmann observes that "the politics of intervention manifest as selective human rights shaming. This entails highly dichotomised propaganda campaigns during which 'enemy' countries are marked for 'humanitarian intervention"' (2017: 219). As such, propaganda is a form of information operation within the framework of the strategic level of information programme that is intended to support the physical political and military goals and objectives within a given area of operations by shaping and influencing the information space that exists in and around the physical sphere.

\footnotetext{
${ }^{2}$ Media priming is a cognitive psychological concept where coverage of various issues in terms of in terms of the quantity and quality of the coverage sends a signal to content consumers in order for them to subjectively evaluate the given situation to affect their opinion, perception and reactions. For more on priming see https://www.utwente.nl/en/bms/communication-theories/sorted-by-cluster/Mass-Media/Priming/.
} 
As noted by Entman (2004), political actors need to 'sell' their versions and framings of political events to the news media and public, which determines whether or not the suggested policy is accepted as legitimate or not. To aid in the perceived legitimacy and acceptance there is a scripted narrative of exaggerated risks and dangers and of opposing sets of projected realities of good and evil. The problem is defined in a very simple way, and in emotional terms within sets of frames. ${ }^{3}$ These frames are then often repeated to reinforce the unambiguous and emotionally compelling story, and to exclude other possible interpretations. The intention is to shape public perception and opinion, and ultimately unify public approval (Entman, 2004: 1). The situation described within this section creates a precarious environment for the role of mass media and journalism, which is nominally guided by the principle of a fourth estate role - a public guardian through acting as a check and balance against any excesses of power by the judiciary, executive and legislative branches of government.

Research by Zollmann (2017a: 13) proposes that "news media allows powerful agents and groups to intentionally manage the news arena and thereby guide journalistic selection and production processes." One of the more infamous examples of Zollmann's observation is seen in the case of the 2003 Iraq War. This was a major global media event, which the U.S. broadcasting networks framed as Operation Iraqi Freedom (the official Pentagon concept for the military operation) and was a conduit for Bush administration and Pentagon propaganda (Kellner, 2004: 329). Some former journalists also take a much less optimistic view of this assumed role. Payne (2005) characterised mass media as being an instrument of war, owing to the fact that coverage of conflict influences public perception and opinion of the event, regardless of the nature of the intentions of individual journalists.

\section{Framing the Syrian Conflict}

The Syrian conflict began with protests on 26 January 2011 and rapidly escalated into a full uprising on March 15 of that year, and has been the bloodiest of the conflicts associated with the revolutionary wave of the Arab Spring (Bhardwaj, 2012: 84). The carefully scripted framing of the physical sphere in the information sphere reveals the geopolitical lines of this conflict, which if broken down into the core operational aims involves the task of regime change versus regime stability (to overthrow Bashar al Assad or keep him in power). In 2012

\footnotetext{
${ }^{3}$ Entman (2004: 5) defines his understanding of framing as "selecting and highlighting some facets of events or issues, and making connections among them so as to promote a particular interpretation, evaluation, and/or solution."
} 
a Defence Intelligence Agency report characterised the Syrian conflict as a proxy war with geopolitical dimensions that involved global and regional actors. This report also contradicted an important mainstream frame of the time, which suggested that the 'moderate' rebels were leading the opposition to Assad by stating categorically that radical Jihadist elements were the main driving force in the opposition ranks. This report revealed a significant difference how political and military leaders were projecting the conflict in the information sphere and the apparent realities on the ground in the physical sphere.

Previous research has demonstrated that not all wars and conflicts are covered equally in the mainstream mass media, a change in the quality of coverage is seen depending on whether an actor is labelled as being an 'enemy' or identified as being the 'bad' or 'evil' actors in a given conflict. Zollmann (2017) investigated six different cases, including a Syrian case from 2012, searching through mass media sources in the US, UK and Germany, came across bias in the coverage that favoured the official standpoint. There was a concerted propaganda campaign in the opening of the Syrian War that was intended to script the conflict (establish the 'orthodoxy' of accepted knowledge), establish the brands and reputations of the primary actors (expectation management), and to make other interpretations difficult to communicate (as they would be rejected or the messenger labelled an "Assadist" or "stooge of Putin/Iran") (Simons, 2018).

Zollmann noted that the Houla Incident from May 2015 (in which 116 civilians were killed) "constituted a tipping point" and "paved the way for sanctions against Syria." Zollmann notes "Houla had quickly served as a symbol for Syrian [government] villainy. Yet again, the factual record of Houla does not suggest a monolithic picture" (2017: 101). Civilian suffering was highlighted with the use of indignation, moral and ethical judgements in order to generate a sense of outrage among the public. News reports emphasized the villainy of the Syrian government and army, whilst simultaneously downplaying the activities of the Syrian 'Opposition' (Ibid: 115). The nature of the news content demonstrated the propaganda value of news content as a mechanism for driving the military intervention agenda. This observation fits with Bernays (1947) proposition that the quality and timing of the news was not accidental, but rather a deliberate strategy intended to engineer public consent.

The Syrian conflict is an extremely complex and multi-faceted event, which has been argued by some from an early point (Malantowicz, 2013) as having the characteristics of old

\footnotetext{
${ }^{4}$ Allday, L., Controlling the Narrative on Syria, MR Online, https://mronline.org/2016/12/13/allday131216html/, 13 December 2016 (accessed 25 June 2018)
} 
and new wars simultaneously. New wars through the basic assumptions concerning actors, methods applied, spread of violence and war economy. Old wars are in reference to the ideological and political background. The conflict is highly scripted along diametrically opposed polar opposites of assumed and projected norms and values assigned to the various actors engaged in the conflict, which in turn affects the framing used in the analysis and reporting of the conflict (Simons, 2016). Intelligence assessments of Syria have referred to it as a proxy war (DIA, 2012), there are also voices in academic literature that also refer to Syria as an example of a proxy war where the different sides involved are becoming increasingly reliant on external patrons, and warn of possible long-term negative consequences of actors seeking regime change as the consequences may prove to be producing an even more dire situation (Hughes, 2014). Although the Syrian conflict is often framed within the context of humanitarian norms and values, the conflicting geopolitical objectives by various actors are another means of framing the war.

As early as 2012, a Royal United Services Institute (RUSI) report was published, which recognised the geopolitical dimensions of the conflict (regional and global), the negative effects of the war in Libya that had the effect of limiting foreign policy options (of direct military intervention), yet tried to frame the 'inevitability' of a "collision course for intervention." The US approach was also similar in how the conflict was framed. A 2014 Congressional Research Service (CRS) report (Blanchard et al, 2014) outlined the highly complex nature of the conflict and the seemingly contradictory aims - fighting Islamic State, volatile systems of alliances, the possibility of volatility spreading out from Syria to a wider area, isolating and 'punishing' the Syrian government, and the train and equip programme for rebels. By the time of an Institute for the Study of War report emerged on US strategy in Syria in March 2017, the frames were not changed from the 2014 CRS report. But a new threat frame had been added, the influence of Iran and Russia in Syria, which was characterised as a risk and threat to US interests in Syria and the Middle East, but also a threat to the "global order" (Cararella et al, 2017: 25). Within this context, the US-led coalition sought to recreate the so-called Libya-scenario (to invoke the Responsibility to Protect (R2P) in a 'civil war') in Syria as the framing of the conflict in its early stages bore a strong resemblance. However, the opinion and perception of R2P's application in Libya was controversial and differed markedly from others on the United Nations Security Council, such as China and Russia. The memory of Libya and R2P influenced the ability of the attempt to apply this tool to Syria (Morris, 2013; Thakur, 2013). This is a demonstration of the element of unpredictability that occurs in the cognitive processing of communicated 
material from the information sphere. The information sphere has evolved in terms of the rapidity in disseminating data in order to prime and mobilise audiences.

Different groups have been opposing each other on social media, promoting their own version of events and attacking their opponent's version, such as the role and work of the Syrian Electronic Army (Government aligned) and the Syrian Free Army (Opposition aligned) on platforms such as Facebook and Twitter (Shehabat, 2013). Thus on the one side, the Assad government seeks to convey messages and images of a brave national leader with the interests of the Syrian people at heart, whilst forces seeking regime change seek to convey an image and reputation of the brutality of Assad and highlight the suffering of civilians (Seo \& Ebrahim, 2016). Social media provides a platform to disseminate instant communications to a potentially large audience, and given the format of the medium it can exert a more powerful emotional response with the use of video material as opposed to simply text. The reasoning and logic used can also be selective or faulty in order to meet the political objectives of the propaganda as explained by Taylor (2003: 1-16) and Shabo (2008: 5). There are also wider discussions on the role of Western governments in Syria that are periodically appearing in the public information space.

Periodically, a number of articles do appear in mainstream mass media sources that shed some critical light on aspects of the involvement of Western governments in Syria. These articles normally fall short of questioning whether or not there should be involvement, but rather the exact nature of a limited range of activities. One such article from 2016 detailed the British government's help to rebel groups fighting in Syria for developing and producing communications. "In both the foreign and domestic campaigns, the government's role is often concealed. Messages are put out under the banner of apparently independent groups community organisations in the UK, and armed groups in Syria." 5 But rather than criticise this role, it was justified along the lines of the main official (Government and Ministry of Defence in particular) narratives - promoting moderate values of the revolution, turn public opinion against the Assad government and ISIS. A story that was more critical of the official version of events appeared over one year later when the BBC programme Panorama alleged that the Foreign and Commonwealth Office and the Conflict, Stability and Security Fund may have allowed funds intended for poverty reduction to be directed to an extremist group in

\footnotetext{
${ }^{5}$ Cobain, I., Ross, A., Evans, R. \& Mahmood, M., How Britain Funds the 'Propaganda War' Against ISIS in Syria, The Guardian, https://www.theguardian.com/world/2016/may/03/how-britain-funds-the-propaganda-waragainst-isis-in-syria, 3 May 2016 (accessed 9 May 2016)
} 
Syria. ${ }^{6}$ Unlike the previously mentioned article, this opinion article identified a problem and proposed a solution.

Norton-Taylor characterises Syria as a "geopolitical earthquake." The reasons for doing so are made clear in his Guardian article. He states (in 2015) that the world was witnessing a significant turning point in global affairs through events in Syria. Stating that a 'weary' West led by the US was following well-rehearsed causes, and Russia had put them on the back foot with "Putin's decisive intervention in Syria."7 This implies that geopolitics are at work in a local/regional and a global scale. A situation, such as this one, has implications for the quality and reliability of information flows, based on Payne's (2005) characterisation of media as being an instrument of war. A stinging criticism of Western media coverage of Iraq and Syria was by Cockburn (from The Independent), who stated that the level of fabricated news and on-sided reporting in the news agenda on Syria has not been witnessed since the First World War. An underlying reason for the situation was proposed. "The real reason that reporting of the Syrian conflict has been so inadequate is that Western news organisations have almost entirely outsourced their coverage to the rebel side." 8

The effects of mass media reporting on the Syrian conflict have also been the topic of discussion. A March 2018 article in the Atlantic declared that the CNN-Effect had died in Syria. According to the CNN-Effect of the 1990s, vivid coverage of humanitarian crisis by 24-hour news networks influenced government decisions to use military force. ${ }^{9}$ United Nations expert Richard Gowan suggested one reason for the death of the CNN-Effect was "the effect of unverified social media posts and slick state propaganda on a civil war wrapped in a proxy war inside a great-power war" that has resulted in a deluge of information of dubious quality. ${ }^{10}$ Fairness and Accuracy in Reporting (FAIR - a media watcher based in the US) does not refer to mainstream Western media coverage of the Syrian conflict as propaganda, it is extremely critical of the quality of news and notes the various

\footnotetext{
${ }^{6}$ Osamor, K., Panorama's Syria Allegations Show the UK's Aid Needs Greater Transparency, The Guardian, https://www.theguardian.com/commentisfree/2017/dec/04/panorama-syria-allegations-uk-aid-transparency-bbc, 4 December 2017 (accessed 5 December 2017)

${ }^{7}$ Norton-Taylor, R., Syria: A Geopolitical Earthquake, The Guardian, https://www.theguardian.com/news/defence-and-security-blog/2015/oct/06/syria-a-geopolitical-earthquake, 6 October 2015 (accessed 29 May 2018)

${ }^{8}$ Cockburn, P, Who Supplies the News?: Misreporting in Syria and Iraq, London Review of Books, https://www.lrb.co.uk/v39/n03/patrick-cockburn/who-supplies-the-news, 2 February 2017 (accessed 16 February 2018)

${ }^{9}$ Although the academic debates on the existence or not of the CNN-Effect were somewhat inconclusive, the arguments and counter-arguments can centre on whether mass media outlets are a power independent actor or a useful tool of legitimisation.

${ }^{10}$ Friedman, U., The 'CNN-Effect' Dies in Syria, The Atlantic, https://www.theatlantic.com/international/archive/2018/03/cnn-effect-syria/554387/, 1 March 2018 (accessed 7 March 2018)
} 
inconsistencies in the narratives and framing. "Anglo-American press coverage of the Syrian situation has grossly misled readers about their governments' role in the catastrophe, and has urged audiences to accept greater Western military intervention in the country without examining the implications of such a move." ${ }^{11}$ Different actors and interests are attempting to compete in an increasingly crowded information marketplace on the Syrian conflict, which is often couched in opposing sets of norms, values and visions. Where the ability to persuade and influence the cognitive sphere via symbolic representations of the physical sphere through the information sphere is seen as the path to increasing the operational capacity and power of the winners.

The dominant frames in Anglo-US media already existed well before the Douma incident, where Assad was the villain and 'armed opposition' were the heroes, US and UK positioned themselves as saviours and Russia and Iran as spoilers. A highly subjectively simplified projected reality of good versus evil was prevalent in mainstream press, which supported official government positions on the policy of regime change (Simons, 2016 \& 2018; Zollmann, 2017a). The audience had also been subjected to the false logic that if a chemical weapons attack occurs, the Syrian government is the likely culprit (Simons, 2016a).

\section{Case Study: Western Media Coverage of the Syrian Conflict at Key Points}

\section{Method}

The approaches to textual analysis shall include content analysis (quantifications of different elements in text), argumentation analysis (the structure of argumentation used), and the qualitative analysis of ideas in the content (with a focus on propaganda) (Boréus \& Bergström, 2017:7-9). The combination of these approaches is expected to yield results on the ontology (what exists) and epistemology (knowledge and how we 'know' things) of reactions to mass mediated textual depictions of the Douma event within the context of the Syrian conflict. The objects of study include power, people, policy, oppression and freedom, war and peace and so forth (Boréus \& Bergström, 2017:1-2). The mass media texts then contextualise the relationships according to perceived and projected power in the constructed social world order of mankind, such as justice and injustice, powerful and powerless, legitimate and illegitimate, worthy and unworthy. The analysis of the framing of the empirical material of this case study will follow the method of Entman (2004: 5).

\footnotetext{
${ }^{11}$ Shupak, G., Media Erase US Role in Syria's Misery, Call for US to Inflict More Misery, FAIR, https://fair.org/home/media-erase-us-role-in-syrias-misery-call-for-us-to-inflict-more-misery/, 7 March 2018 (accessed 10 March 2018)
} 
- Defining effects or conditions as problematic;

- Identifying causes;

- Conveying a moral judgement;

- Endorsing remedies and improvements.

The case study involves analysing media reports and coverage in the first four days of the April 2018 chemical weapons event in Syria at Douma. This four day window is too short a period to launch and conclude an official investigation into the event, let alone to conclusively and objectively assign blame on any guilty party. But this period is critical in terms of propaganda and getting one's version of events communicated through the information sphere in order to shape opinion and perception in the cognitive sphere. In order to do this, in such a short space of time, propaganda seems to be the most effective means to quickly prime and mobilise the audience through the use of emotion, rather than rational logic. It should be noted UK public opinion was firmly against any military intervention at the time of the incident by a ratio of two to one, ${ }^{12}$ and the US polls indicated $50 \%$ of respondents approved of the missile strikes. ${ }^{13}$

In terms of the newspapers chosen for analysis: Guardian, Independent (UK), Washington Post and Washington Examiner (USA) - leading mainstream newspapers in two of the three countries that launched military strikes against Syria (United States, United Kingdom and France) in the wake of the events in Douma. The reason for choosing these particular newspapers is because they are influential, well-established publications with a large circulation, plus all of the chosen newspapers have no paywall on content (providing open access for both researcher and other readers). This means these newspapers are able to reach many people globally and therefore are a more likely medium of communication for the governmental view on the issue (owing to these papers being able to contact and persuade officials to speak to them and officials understanding the communication potential of the outlets). However, as there are only four newspapers in two countries over a four day period being investigated by the author, the results should be considered as being indicative and not generalizable.

\footnotetext{
${ }^{12}$ Curtis, C., By two to one, the public oppose missile strikes on Syria, YouGov, https://yougov.co.uk/topics/politics/articles-reports/2018/04/12/two-one-public-oppose-missile-strikes-syria, 12 April 2018 (accessed 18 December 2018)

${ }^{13}$ Reinhart, R. J., Snapshot: Half of Americans Approve of Strikes on Syria, Gallup, https://news.gallup.com/poll/232997/snapshot-half-americans-approve-strikes-syria.aspx, 24 April 2018 (accessed 18 December 2018)
} 


\section{Case Study and Sample Background}

The Office for the Prevention of Chemical Weapons (OPCW) reported an "alleged incident" involving the use of toxic chemicals as a weapon in Douma, Syria at 1600 on 7 April 2018. Casualties from the incident varied from 40-70 deaths and hundreds of injuries resulting from exposure to a toxic substance. The initial reports on the nature of the substance were mixed and unclear, with some allegations of sarin, others stating chlorine and further reports suggesting a mixture of these chemicals. Extensive use of on-line postings was made by various parties to influence opinion and perception of the event. A blame game ensued where the 'armed opposition' accused the Syrian government of carrying out the attack, and the Syrian government blamed Jaysh al Islam of fabricating the incident in order to incriminate the Syrian government and military (OPCW, 2018: 3). Thus from the very moment of awareness of the incident, different subjective and politicised accounts of the event in the physical sphere were communicated through the information sphere. The role of the OPCW is stated as being an independent observer that investigates such events, but not an observer that apportions blame (OPCW, 2018: 4). OPCW has been operating in Syria for a number of years in this capacity.

Since 2015 the OPCW has held a mandate to investigate such reported incidents in the country. On 10 April clearance and the necessary formalities were concluded between the OPCW and the Syrian government that permitted a team of investigators to be dispatched, an advanced team was sent on 12 April, a follow-up team the next day and the full team by 15 April. The team began its investigation work from 18 April at the site of the alleged attack, but encountered unexploded munitions and small arms fire. This delayed the visit to the first site until 21 April (OPCW, 2018). The OPCW reported the analysis results of the sampling.

The results of analysis of the prioritised samples submitted to the designated laboratories were received by the FFM team on 22 May 2018. No organophosphorus nerve agents or their degradation products were detected, either in the environmental samples or in plasma samples from the alleged casualties. Various chlorinated organic chemicals were found in samples from Locations 2 and 4, along with residues of explosive (OPCW, 2018: 10).

The interim results of the OPCW, which were released in July 2018 (three months after the alleged incident) cast significant doubt on the framing used by mainstream Western 
politicians and mass media. The significance of the lessons from this event, where mass media reported from 7 April (the day of the event) and 10 April (the day arrangements were made for an OPCW team to visit the site, show that the conclusions in the media and political circles were already reached before any technical investigation was even initiated. This raises questions as to the exact nature and basis of the 'evidence' to support the claims made in the information sphere.

In July 2018 a manual search was conducted on the search engines of the four newspapers analysed - Guardian, Independent, Washington Post and Washington Examiner. The content sought was according to the earlier mentioned criterion - related to the events of $7^{\text {th }}$ of April 2018 in Douma and the next three days on the chemical incident. Each search was physically sorted by the author in to relevant and irrelevant articles. The following table summarises the results of this search.

Table One: Article Sample

\begin{tabular}{|l|l|l|l|l|l|l|}
\hline \multirow{2}{*}{ Country } & \multirow{2}{*}{$\begin{array}{l}\text { Media } \\
\text { Outlet }\end{array}$} & \multicolumn{3}{|l|}{ Article Sample Count } & \multirow{2}{*}{ Total } \\
\cline { 3 - 7 } & April 7 & April 8 & April 9 & April 10 & \\
\hline \multirow{2}{*}{$\begin{array}{l}\text { United } \\
\text { Kingdom }\end{array}$} & Guardian & 1 & 5 & 4 & 6 & 16 \\
\cline { 2 - 7 } & Independent & 1 & 3 & 6 & 6 & 16 \\
\hline $\begin{array}{l}\text { United } \\
\text { States }\end{array}$ & $\begin{array}{l}\text { Washington } \\
\text { Post }\end{array}$ & 1 & 4 & 12 & 8 & 25 \\
\cline { 2 - 6 } & $\begin{array}{l}\text { Washington } \\
\text { Examiner }\end{array}$ & 0 & 6 & 15 & 6 & 27 \\
\hline
\end{tabular}

\section{Selected Anglo-United States Media Coverage of Douma}

The first newspaper to be analysed for content on the events of Douma and the immediate aftermath was the Guardian in the United Kingdom. There was only one article that was published on the first day of the Douma event. This article notified of a "suspected chemical attack" on the rebel held part of the area. Although the use of language indicates a certain level of uncertainty that the event happened, there was simultaneously an accusative tone. This was clearly evident in an editorial that appeared on 8 April, which accused Bashar al- 
Assad of the 'crime' and urged world 'responsibility' in a heavily emotional rhetoric. ${ }^{14}$ Heavy use is made of diametrically opposed sets of values and norms, where Assad and Putin are scripted as the super villains, the 'rebels'/'opposition' are the heroes, the victims are the Syrian people, and the possible saviours are the US-led alliance.

One of the first articles on Douma set many of the frames that were the foundation for the telling of this story. The reference to a "suspected chemical attack" as opposed to a confirmed attack, a great deal of graphic and emotionally charged descriptions of the victims and especially children, there were references to previous cases of alleged chemical attacks that in hindsight revealed serious flaws and errors in the reporting (Simons, 2016a). "The incident was the latest in a string of alleged chemical attacks on the enclave of eastern Ghouta."15 The video shown in the article bore the brand of one of the rebel groups, which is in-line with Cockburn's criticism of Western mass media 'outsourcing' to rebel groups. Follow-up articles maintained the foundation of the selected news frames and added further information and 'evidence.' There were mentions of a "toxic gas attack" and mentions of the previous events where chlorine and sarin were used. As a possible connection for a possible motive, a breakdown in negotiations to evacuate (term "exile" was used) rebels from the area. Blame was assigned to the Syrian government, Russia and Iran. Different endorsements of condemnation were published, including from Pope Francis, but also from the US State Department who made the "demand for an international response if confirmed." They also put the blame on the Russian government by virtue of the fact that they were supporting the Syrian government. The UK Foreign Office was quick to blame Assad as "further proof of Assad's brutality against innocent civilians and his backers' callous disregard for international norms." 16 The reporting so far has been dedicated to creating the frames and the 'demand' for a response.

This created the context for introducing possible 'solutions' to the crisis situation. A concerted call for military action was made, not if any other options should be considered. "The response to a 2017 chemical attack was largely symbolic; this time it could be more

\footnotetext{
${ }^{14}$ Editorial, The Guardian View on the Syrian Chemical Attack: Assad's Crime - the World's Responsibility, The Guardian, https://www.theguardian.com/commentisfree/2018/apr/08/the-guardian-view-on-the-syrianchemical-attack-assads-the-worlds-responsibility, 8 April 2018 (accessed 12 July 2018)

${ }^{15}$ Reuters, Aftermath of Suspected Chemical Weapons Attack in Rebel-Held Douma in Syria - Video, The Guardian, https://www.theguardian.com/uk-news/video/2018/apr/08/the-aftermath-of-a-suspected-chemicalattack-on-syrian-rebel-held-douma-video, 8 April 2018 (accessed 12 July 2018)

${ }^{16}$ Shaheen, K., Dozens Killed in Suspected Chemical Attack on Syrian Rebel Enclave, The Guardian, https://www.theguardian.com/world/2018/apr/08/syrian-government-accused-of-chemical-attacks-on-civiliansin-eastern-ghouta, 8 April 2018 (accessed 12 July 2018)
} 
comprehensive."17 Different military operation scenarios were considered and possible reactions from the Syrian military and Russia. Britain's options and more specifically those of the May government were discussed, most often in a value/norm basis as opposed to operational matters or in the context of international law. ${ }^{18}$ The decision was seemingly already made for military action, reporting was an exercise in attempting to emotionally prime and mobilise the public.

The next newspaper to be analysed was the Independent (United Kingdom). In terms of the blame game, the Independent is much quicker to assign the blame and to detail alleged events. There is still an implied element of uncertainty in the information though, which is found in the title of the article - 'dozens of civilians killed in chemical weapons attack' (rather than prefixing with "alleged"). Different NGOs support the main frame of the human suffering and blame elements, in addition to the US State Department that is quoted as saying "it is monitoring the situation and that Russia should be blamed if chemicals were used." Specifically the article mentions that "barrel bombs" containing chemical weapons were dropped by Syrian military aircraft. A 'rebel' military spokesman from Jaish al-Islam was quoted as blaming the Syrian government. ${ }^{19}$ The blame game and human suffering frames were intensified on 8 April, President Donald Trump is quoted as saying that there may be a "big price to pay" and his character assassination reference of "animal Assad." An article went as far as to state that a "sarin barrel bomb" was used in the 'chemical weapon attack'. Although the article also covered Russia's warning of the consequences of an intervention being waged under false pretences. Conflicting reports were evident, although a continued heavy reliance on 'opposition/rebel' sources - "The pro-opposition Ghouta Media Centre alleged that a helicopter had dropped a barrel bomb containing sarin, and another organisation claimed that a hospital had been hit by a chlorine bomb."20 As with the Guardian's editorial, the Independent also runs one that matches the framing of blame and

\footnotetext{
${ }^{17}$ Chulov, M., What Could the US Target in Syria and How Likely is Russia to React?, The Guardian, https://www.theguardian.com/world/2018/apr/10/what-could-the-us-target-in-syria-and-how-might-russia-react, 10 April 2018 (accessed 12 July 2018)

${ }^{18}$ Wintour, P., Retaliation in Syria: What are May's Options?, The Guardian, https://www.theguardian.com/politics/2018/apr/10/signs-of-tory-division-over-uk-support-for-us-assault-onsyria, 10 April 2018 (accessed 12 July 2018)

${ }^{19}$ Osborne, S., Syria Civil War: 'Dozens of Civilians Killed in Chemical Weapons Attack' on Douma in Eastern Ghouta, Says Monitor, Independent, https://www.independent.co.uk/news/world/middle-east/syria-chemicalweapons-civilians-killed-douma-eastern-ghouta-damascus-a8294296.html, 7 April 2018 (accessed 12 July 2018)

${ }^{20}$ Lusher, A., Syrian Government Accused of Using Nerve Agents as Death Toll from Douma 'Chemical Weapons Attack' Rises, Independent, https://www.independent.co.uk/news/world/middle-east/syria-chemicalweapons-attack-latest-sarin-douma-eastern-ghouta-nerve-agent-chlorine-russia-us-uk-a8294741.html, 8 April 2018 (accessed 12 July 2018)
} 
accountability. Assad and Russia are to blame and the 'international community' has the duty to hold them to account. ${ }^{21}$

From 9 April there was still reporting on the blame and human suffering, but there was a perceptible shift and addition of the response frame, which was more about what kind of military action should be undertaken. An article claimed through a quote that the pictures of dead children mean nothing to countries like Russia, ${ }^{22}$ which is an emotional assertion based on spurious grounds that a concrete and verified fact. A series of articles discussed the discussed the various military options available, ruling nothing out, in a typical example of these frames built the case of guilt and the 'need to act' based upon the assertions and assumptions of interested parties. Interested this particular article uses the same term of reference as in the Guardian of "alleged." A revealing quote, which alludes to possible geopolitical elements can be found in the article too. "Western allies have looked to increase pressure on the Kremlin for its relationship with Mr Assad, as calls increase for co-ordinated international action over the alleged chemical attack." ${ }^{23}$ The $10^{\text {th }}$ of April witnessed articles consolidating the case for war, such as Tony Blair's statement that there had to be military intervention because without it there would be negative consequences. ${ }^{24}$ The general tone of the articles on the $10^{\text {th }}$ of April is projecting consensus among Western leaders on the necessity for military intervention in Syria. No mention is made of the deception used to initiate the Iraq War in 2003 or the disastrous consequences that followed the Libya intervention in 2011 that was lamented in a House of Commons report (House of Commons, 2016).

Washington Post (United States) was the third newspaper to have its content on the Douma event from 7-10 April examined and analysed. The first brief report on 7 April quoted rebel sources that the Syrian government dropped a barrel bomb filled with "poisonous chemicals", various NGOs and rebel sources were quoted as to the nature and extent of the

\footnotetext{
${ }^{21}$ Editorial, The Chemical Attack in Syria is an Indictment of the International Community's Failures, Independent, https://www.independent.co.uk/voices/editorials/chemical-attack-syria-damascus-russia-putintrump-a8295021.html, 8 April 2018 (accessed 12 July 2018)

${ }^{22}$ Buncombe, A., US Attacks Moscow Over Suspected Syria Chemical Attack: 'Pictures of Dead Children Mean Nothing to Countries Like Russia', Independent, https://www.independent.co.uk/news/world/middle-east/syriachemical-attack-latest-assad-haley-un-douma-blood-children-repercussions-a8297001.html, 9 April 2018 (accessed 12 July 2018)

${ }^{23}$ Wilts, A., Donald Trump Says 'Nothing is off the Table' for US Response to Alleged Syria Chemical Attack, Independent, https://www.independent.co.uk/news/world/americas/us-politics/donald-trump-syria-chemicalweapons-attack-latest-assad-regime-douma-a8296581.html, 9 April 2018 (accessed 12 July 2018)

${ }^{24}$ Kentish, B., Tony Blair Says that UK Should Launch Military Action in Syria Because 'Non-Intervention has Consequences', Independent, https://www.independent.co.uk/news/uk/politics/tony-blair-uk-syria-militaryaction-kosovo-dourma-chemical-attack-us-un-a8297336.html, 10 April 2018 (accessed 12 July 2018)
} 
alleged attack, and the official Syrian government denial that was carried by the UK media. ${ }^{25}$ The article was relatively short with the briefest details, although the frame of the accusations was now set. From 8 April the reporting became much more emotionally based, even though still using the caveats of linguistic uncertainty, and began under these circumstances to introduce the notion of military retaliation for the alleged attack. "Apparent chemical weapons attack" was the term used to describe the event in the physical domain. Vivid details and video was used to reinforce the frame of civilian suffering, and children in particular. It was stated specifically that the likely chemical was chlorine. ${ }^{26}$ Previous actual and alleged chemical attacks were discussed, which gave the impression of a historical context that tended to support the scripted propaganda frames of the roles of the different actors.

An opinion article on 9 April criticised Trump for not using military force on Syria and connected Trump together with Syria, Iran and Russia in an emotional and value-based argument. "The result: another grotesque chemical-weapons attack that reveals the barbarism of the Russian, Iranian and Syrian regimes - and the moral and intellectual bankruptcy of the Trump regime." 27 The geopolitical dimensions of the Syrian conflict were apparent in the reporting too, such as "Russia is expected to stick up for Assad." 28 Numerous articles appeared on the $9^{\text {th }}$ and $10^{\text {th }}$ of April (as was the case with the UK newspapers) engaging in the blame game and calling for a stronger military response that the one the year before in Idlib. This was most clearly seen in an editorial opinion with the headline "A few cruise missiles from Trump won't stop Syria's war crimes." 29 Other articles spoke on behalf of Americans, calling for military action as a 'humanitarian response' - "Americans feel a moral obligation to help humanitarian victims (like those in Syria) with military force. ${ }^{30}$ One of

\footnotetext{
${ }^{25}$ Reuters, Rebels Assert Chemical Attack by Government, Washington Post, https://www.washingtonpost.com/national/world-digest-april-7-2018/2018/04/07/12df5bb2-3aa9-11e8-8fd249fe3c675a89 story.html?utm term=.0ec114fb2851, 7 April 2018 (accessed 17 July 2018)

${ }^{26}$ Loveluck, L. \& Cunningham, E., Dozens Killed in Apparent Chemical Weapons Attack on Civilians in Syria, Rescue Workers Say, Washington Post, https://www.washingtonpost.com/world/middle east/dozens-killed-inapparent-chemical-weapons-attack-on-civilians-in-eastern-ghouta--rescue-workers/2018/04/08/231bba18-3ac0$11 \mathrm{e} 8$-af3c-2123715f78df_story.html?utm term=.a610510efc65, 8 April 2018 (accessed 17 July 2018)

${ }^{27}$ Boot, M., The Latest Chemical Attack in Syria Reveals the Bankruptcy of Trump's Policies Toward Assad, Washington Post, https://www.washingtonpost.com/news/global-opinions/wp/2018/04/08/the-latest-chemicalattack-in-syria-reveals-the-bankruptcy-of-trumps-policies-toward-assad/?utm_term=.60eee8321d52, 9 April 2018 (accessed 17 July 2018)

${ }_{28}$ Morello, C., U.N. to meet on chemical attack in Syria, though Russia is expected to stick up for Assad, Washington Post, 9 April 2018 (accessed 17 July 2018)

${ }^{29}$ Editorial, A few cruise missiles from Trump won't stop Syria's war crimes, Washington Post, 10 April 2018 (accessed 17 July 2018)

${ }^{30}$ Kreps, S. \& Maxey, S., Americans feel a moral obligation to help humanitarian victims (like those in Syria) with military force, https://www.washingtonpost.com/news/monkey-cage/wp/2018/04/10/americans-feel-amoral-obligation-to-help-humanitarian-victims-like-those-in-syria-with-militaryforce/?utm term=.19a60d73d2fe, Washington Post, 10 April 2018 (accessed 17 July 2018)
} 
the final articles to appear chronologically in the selected period announced the planned arrival of chemical inspectors in the area of the alleged attack, ${ }^{31}$ even though the frames of guilt and retribution had already been decided without any complete technical investigation.

The final newspaper in this chapter to be examined and analysed for news content on the April 2018 Douma chemical weapons event was the Washington Examiner. An opinion article appeared very early in the opening coverage of Douma on 8 April, the author laid the blame with Assad, but used language that suggested less than complete certainly of the guilty party. "Why you can be almost certain Bashar Assad is responsible for the Syrian chemical weapons attack" and this is based on the presumed content of intelligence briefings delivered to Trump. ${ }^{32}$ There is a high degree of assertion and assumption in the logic of this opinion article in assigning the blame that is characterised as being "almost certain" some 24 hours after a remotely occurring event in a conflict known for the heavy use of propaganda and deception. Many articles on 8 April called for condemnation and a military response to the alleged event that occurred the day before. These calls were often made with the use of emotionally-based value and norm lobbying - "Trump reacts to 'mindless' chemical attack in Syria: 'Big price to pay,' Russia, Iran responsible for backing 'Animal Assad'” (an example of scapegoating and character assassination); 33 "Lindsey Graham: Trump's response to Syria chemical attack a 'defining moment", (imploring Trump to use military action); ${ }^{34}$ "Paul Ryan: 'Responsible nations' cannot tolerate Syria chemical attack" (an example of bandwagoning propaganda where the speaker uses pathos to try rally support by joining the 'moral high ground'). ${ }^{35}$ Although the headlines did not often denote the uncertainty that other newspapers did, there was still use of such wording as "reported chemical attack" (as

31 Morello, C., Chemical weapons inspectors head to Syria as White House mulls response to attack, https://www.washingtonpost.com/world/national-security/chemical-weapons-watchdog-to-send-investigatorsto-syria/2018/04/10/fd18a736-3cd6-11e8-a7d1-e4efec6389f0_story.html?utm term=.64f0b50fb5d7, Washington Post, 10 April 2018 (accessed 17 July 2018)

${ }^{32}$ Rogan, T., Why you can be almost certain Bashar Assad is responsible for the Syrian chemical weapons attack, Washington Examiner, https://www.washingtonexaminer.com/opinion/why-you-can-be-almost-certainbashar-assad-is-responsible-for-the-syrian-chemical-weapons-attack, 8 April 2018 (accessed 17 July 2018) ${ }^{33}$ Chaitin, D., Trump reacts to 'mindless' chemical attack in Syria: 'Big price to pay,' Russia, Iran responsible for backing 'Animal Assad', Washington Examiner, https://www.washingtonexaminer.com/news/trump-reactsto-mindless-chemical-attack-in-syria-big-price-to-pay-russia-iran-responsible-for-backing-animal-assad, 8 April 2018 (accessed 17 July 2018)

${ }^{34}$ Cohen, K., Lindsey Graham: Trump's response to Syria chemical attack a 'defining moment', Washington Examiner, https://www.washingtonexaminer.com/news/lindsey-graham-trumps-response-to-syria-chemicalattack-a-defining-moment, 8 April 2018 (accessed 17 July 2018)

${ }^{35}$ Cohen, K., Paul Ryan: 'Responsible nations' cannot tolerate Syria chemical attack, Washington Examiner, https://www.washingtonexaminer.com/news/paul-ryan-responsible-nations-cannot-tolerate-syria-chemicalattack, 8 April 2018 (accessed 17 July 2018) 
opposed to confirmed). ${ }^{36}$ Talking heads in mainstream political circles are used to try and consolidate the framing through the use of ethos, where the standing of the public figure is used as a confirmation of the articles' framing.

April 9 was a day of reporting that revolved around the frame of what kind of military response was needed as opposed to a more open debate that could involve something other than a military option. A typical example of this type of framing was seen with an article headlines "The US is drawing up several options for striking Syria after chemical weapons attack, Pentagon sources say." ${ }^{37}$ One article proved to be somewhat of an outlier as it gave voice to Russia's denial of any culpability in the alleged chemical weapons attack. ${ }^{38}$ There was also some evidence of the use of deflection by the Trump administration, by blaming President Obama for handing Trump the "mess" and Trump for not doing enough in Syria. "Vietor's tweet followed what officials believe was a poison gas attack near Damascus, Syria, on Saturday, which claimed the lives of 40 people and injured 500 more. The U.S. suspects the Syrian government to be behind the incident." 39 Therefore, between the lines, even at this stage there is no absolute certainty as to the nature of the event and who is responsible. Coverage of Tucker Carlson's questioning of the legitimacy of the reported chemical attack, ${ }^{40}$ points to the Washington Examiner providing some space to contra voices.

By 10 April the frames were in place before the OPCW team's physical deployment to investigate the claims of chemical weapons being used. Some content, an opinion article, even called for the assassination of President Bashar al-Assad. ${ }^{41}$ The US officials continued

\footnotetext{
${ }^{36}$ Cohen, K., UN Security Council to hold emergency meeting in response to reported chemical attack in Syria, Washington Examiner, https://www.washingtonexaminer.com/news/un-security-council-to-hold-emergencymeeting-in-response-to-reported-chemical-attack-in-syria, 8 April 2018 (accessed 17 July 2018)

37 McIntyre, J., The US is drawing up several options for striking Syria after chemical weapons attack, Pentagon sources say, Washington Examiner, https://www.washingtonexaminer.com/policy/defense-nationalsecurity/the-us-is-drawing-up-several-options-for-striking-syria-after-chemical-weapons-attack-pentagonsources-say, 9 April 2018 (accessed 17 July 2018)

${ }^{38}$ Gehrke, J., Russia: It's not 'logical' to blame Moscow for the chemical attack in Syria, Washington Examiner, https://www.washingtonexaminer.com/policy/defense-national-security/russia-its-not-logical-to-blame-moscowfor-the-chemical-attack-in-syria, 9 April 2018 (accessed 17 July 2018)

${ }^{39}$ Lim, N., Obama national security spokesman: Trump 'was handed a mess' with Syria, Washington Examiner, https://www.washingtonexaminer.com/news/obama-national-security-spokesman-trump-was-handed-a-messwith-syria, 9 April 2018 (accessed 17 July 2018)

${ }^{40}$ Leach, K., Tucker Carlson is questioning legitimacy of reported Syrian chemical weapon attacks, Washington Examiner, https://www.washingtonexaminer.com/news/tucker-carlson-is-questioning-the-legitimacy-of-reportsof-syrian-chemical-weapon-attacks, 9 April 2018 (accessed 17 July 2018)

${ }^{41}$ Rubin, M., It's Time to assassinate Assad, Washington Examiner, https://www.washingtonexaminer.com/opinion/its-time-to-assassinate-assad, 10 April 2018 (accessed 17 July 2018)
} 
to try and promote their own independent ability to investigate what had happened, ${ }^{42}$ and the possible Russian backlash against military intervention was downplayed. ${ }^{43}$ The same accusations used in the other newspapers are used here too, with many quotations from 'rebel' sources, suffering civilians frame with the emphasis on children as a particularly vulnerable group, the assigning of blame and formation of the popular framing that has the effect of creating the conventional wisdom and orthodoxy of knowledge on the issue. This information situation and creation of information dominance made it difficult for alternative views to be expressed.

\section{Findings and Conclusion}

This chapter represents an exploratory study in the Measure of Activity and paths of influence via propaganda within the context of the on-going Syrian conflict. It does not represent a Measure of Influence of those activities, which would require an additional study into the intended and unintended influence on opinion and perception of specified target audiences. A total of 84 articles were found and analysed across the four newspapers across the period 7-10 April 2018.

All newspapers carried minimal coverage on 7 April, which was the day the story broke, but increased their coverage significantly from the next day. Coverage in the two UK based newspapers followed a similar pattern in terms of the quantity and quality of the coverage of Douma. Both of the Washington DC-based newspapers peaked the quantity of coverage on the same day on the $9^{\text {th }}$ of April. There were a number of recurring frames across all four media outlets - civilian suffering (focus on children), use of chemical/nerve agents (chlorine or sarin), villain frame (Syrian government, Russia and Iran), hero frame ('NGOs' and rebels), guilt frame (Syrian government and Russia) and need to act frame (call for 'humanitarian intervention').

The media framing closely followed the pattern developed by Entman - defining effects or conditions as problematic; identifying causes; conveying a moral judgement; endorsing remedies and improvements (Entman, 20044: 5). All media outlets observed defined the problematic effect/condition that was the presumed use of chemical weapons in

42 Gehrke, J., State Department: US 'has its own mechanisms' to investigate Bashar Assad, Washington Examiner, https://www.washingtonexaminer.com/policy/defense-national-security/state-department-us-has-itsown-mechanisms-to-investigate-bashar-assad, 10 April 2018 (accessed 17 July 2018)

${ }^{43}$ Rogin, T., Why Putin probably won't retaliate against US strikes on Assad in Syria, Washington Examiner, https://www.washingtonexaminer.com/opinion/why-putin-probably-wont-retaliate-against-us-strikes-on-assadin-syria, 10 April 2018 (accessed 17 July 2018) 
Douma, Syria. The identified causes reported are the assumed actions of the Syrian government and Russia in this conflict. The moral judgement is that the Syrian government, Russia and sometimes Iran too, are assigned the collective guilt. Without any exception, the media outlets all endorsed the use of military force against the Syrian government as a 'remedy' for the situation.

Propaganda was defined in this chapter as having a persuasive function, intending to reach a sizeable target audience, is representative of a specific group's agenda, and makes use of faulty reasoning and/or emotional appeals (Taylor, 2003: 1-16; Shabo, 2008: 5). The reporting analysed met all of these basic criteria - the newspapers have a sizeable and international readership, there is a very strong persuasive element used in the quality of the news reporting, all of the media outlets carried an overwhelming message of the need for military action against the Syrian government, and the reasoning used displayed emotion and faulty reasoning. The heavy emotional use of children (in text and video) and the faulty logic of assumed guilt and that bombing Syria further would 'help' civilians.

All of the media outlets observed quoted 'rebel' or 'opposition forces' frequently, publishing the material at face value, which tends to support Cockburn's criticism that mainstream media have outsourced their reporting to the anti-Assad forces. The NGOs that were often quoted, as a means of 'independent' sources, also have links. Such as the White Helmets that are funded by both the US and UK governments, ${ }^{44}$ both of these governments identified by the Defence Intelligence Agency report (DIA, 2012) as being active participants in a proxy war. The representation of the physical domain in the information domain was crucial in influencing the cognitive domain. Significant gaps between the physical realities and the informational representations were stark at times.

The emotionally-based logic attempts to use the techniques of bandwaggoning and the call for the international community's 'moral responsibility' as a means to prime and mobilise audiences. This is done with a well prepared information space that makes use of heavily scripted propaganda of the primary actors to establish brands and reputations, and therefore establish public expectations (the 'good' side, 'bad' side and so forth). The reaching of moral and ethical conclusions, based on assumption and assertion, before an actual physical scientific investigation has begun (let alone concluded) is one of the tell-tale signs of the tactic of propaganda to support a not so well hidden political and/or military agenda.

\footnotetext{
44 "Conflict, Stability and Security Fund", House of Lords Hansard, UK Parliament. Column 720, https://hansard.parliament.uk/lords/2016-11-02/debates/333BB123-CF19-41CC-A67F0D55E3D477A6/ConflictStabilityAndSecurityFund\#720, 2 November 2016 (accessed 18 July 2018)
} 
Furthermore, the 'evidence' collected and used to build the case against the Syrian government via 'rebel' sources was proven to be wrong by the OPCW's interim report. In reality there is an alignment between the various frames of propaganda and foreign/military policy - to enable 'our' policy and its operational aspects, and to interfere with the opponent's ability to follow their own choices.

\section{References}

Alberts, D. S., Garstka, J. J., Hayes, R. E. \& Signori, D. A. (2001), Understanding

Information Age Warfare, Washington DC: CCRP Publication Series

Bhardwaj, M. (Spring 2012), Development of Conflict in Arab Spring Libya and Syria: From Revolution to Civil War, The Washington University International Review, Volume 1, pp. 7696

Bernays, E. (1947) The Engineering of Consent, The Annals of the American Academy of Political and Social Science, 250, pp. 113-120

Blanchard, C. M., Humud, C. E. \& Nikitin, M. B. D. (17 September 2014), Armed Conflict in Syria: Overview and US Response, Congressional Research Service, RL334487

Boréus, K. Bergström, G. (2017), Analysing Text and Discourse: Eight Approaches for the Social Sciences, Thousand Oaks (CA): Sage Publishing

Cafarella, J., Kagan, K. \& Kagan, F. W. (March 2017), US Grand Strategy: Destroying ISIS and Al Qaeda, Report Four: America's Way Ahead in Syria, Washington DC: Institute for the Study of War

Clarke, M. (25 July 2012), A Collision Course for Intervention, Syria Crisis Briefing, London: RUSI

Defence Intelligence Agency (DIA) (August 2012), Information report, 14-L-0552/DIA/287 
DiMaggio, A. R. (2009), Mass Media, Mass Propaganda: Examining American News in the “War on Terror", Lanham (MD): Lexington Books

Entman, R. M. (2004), Projections of Power: Framing News, Public Opinion, and U.S. Foreign Policy, Chicago: University of Chicago Press

House of Commons Foreign Affairs Committee (14 September 2016), Libya: Examination of Intervention and Collapse of the UK's Future Policy Options, Third Report of Session 201617, HC 119

Hughes, G. A. (2014), Syria and the Perils of Proxy Warfare, Small Wars \& Insurgencies, 25(3), pp. 522-538

Kellner, D. (2004), Media Propaganda and Spectacle in the War on Iraq: A Critique of U.S. Broadcasting Networks, Cultural Studies - Critical Methodologies, 4(3), pp. 329-338

Malantowicz, A. (2013), Civil War in Syria and the New Wars, Amsterdam Law Forum, 5(3), pp. $52-60$

Ministry of Defence (December 2010), Understanding, No. 4 (JPD04), Shrivenham: Joint Doctrine Publication

Morris, J. (2013), Libya and Syria: R2P and the Spectre of the Swinging Pendulum, International Affairs, 89(5), pp. 1265-1283

OPCW (6 July 2018), Interim Report of the OPCW Fact-Finding Mission in Syria Regarding the Incident of Alleged Use of Toxic Chemicals as a Weapon in Douma, Syrian Arab Republic, on 7 April 2018, Technical Secretariat, S/1645/2018

Payne, K. (Spring 2005), The Media as an Instrument of War, Parameters, pp. 81-93

Seo, H. \& Ebrahim, H. (2016), Visual Propaganda on Facebook: A Comparative Analysis of Syrian Conflicts, Media, War \& Conflict, 9(3), pp. 227-251 
Shabo, M. E. (2008), Techniques of Propaganda and Persuasion, Clayton (DE): Prestwick House

Shehabat, A. (2013), The Social Media Cyber-War: The Unfolding Events in the Syrian Revolution 2011, Global Media Journal: Australian Edition, ISSN 1835-2340

Simons, G. \& Chifu, I. (2018), The Changing Face of Warfare in the $21^{\text {st }}$ Century, London: Routledge

Simons, G. (2018), 'Propaganda and the Information War Against Syria: The Latest War for Peace' in Simons, G. \& Chifu, I. (2018), The Changing Face of Warfare in the $21^{\text {st }}$ Century, London: Routledge, pp. 223-239

Simons, G. (2016), 'Good' Battles and 'Bad' Battles: A Comparative Analysis of Western Media Coverage of the Battles of Mosul and Aleppo, Tractus Aevorum, 3(2), pp. 114-138

Simons, G. (2016a), News and Syria: Creating Key Media Moments in the Conflict, Cogent Social Sciences 2.

Taylor, P. M. (2003), Munitions of the Mind: A History of Propaganda from the Ancient World to the Present Day, $3^{\text {rd }}$ Edition, Manchester: Manchester University Press

Thakur, R. (2013), R2P After Libya and Syria: Engaging Emerging Powers, The Washington Quarterly, 36(2), pp. 61-76

Western, J. (2005), Selling Intervention \& War: The Presidency, the Media, and the American Public, Baltimore: John Hopkins University Press

Zollmann, F. (2017), Media, Propaganda and the Politics of Intervention, New York: Peter Lang

Zollmann, F. (2017a), Bringing Propaganda Back into News Media Studies, Critical Sociology, pp. 1-17 